\title{
Attempting intelligibility with the seemingly incomprehensible: Murambi, human remains and the Labour of Care ${ }^{1}$
}

Ashley DeMartini*

\begin{abstract}
In this article, I discuss the work carried out by the employees of the Murambi Memorial, a site commemorating Rwanda's genocide, to highlight how their work-related responsibilities creates an opportunity for the memorial's visitors to have an intelligible encounter with the seemingly incomprehensible presence of human remains. I introduce the concept of the Labour of Care, which provides a basis to think about how the work carried out by Murambi's employees bestows upon the human remains their interpretable qualities. From this basis, I examine how this concept provides a means to think about human remains not simply as material objects, but rather, better understood as subject-come-objects. By doing so, visitors can move beyond idealized notions of redemption and think about humanity's unsettling capacity for violence.
\end{abstract}

Key words: genocide, curation, human remains, Rwanda

Located in the district of Nyamagabe, Rwanda, the Murambi Memorial emerged as a result of the 1994 genocide. Prior to this event, Murambi was under construction to become a polytechnic school for the surrounding region. On 21 April 1994, the pro-Hutu military of President Juvenal Habyarimana —along with other Hutu extremist civilian killing squads, called the Interhamwe-launched an assault on Murambi with grenades, guns and machetes. Tutsi families and individuals, as well as Hutu moderates, fled to Murambi days before the assault. ${ }^{2}$ The local authorities had promised these people that Murambi's grounds would remain a site of refuge. However, when it came under attack, the military cut off food and water, rendering many of those taking refuge in the school grounds too weak to fight back. After the massacre, the official death toll numbered around 27,000 (Kigali Memorial Centre). ${ }^{3}$ The Polytechnic never opened as a school for the professional trades, but rather, it became the grounds for the Murambi Memorial.

Immediately following the genocide, survivors returned to Murambi to recover the bodies that the Hutu militias had tossed into shallow mass graves. Some of these survivors proceeded to preserve the bodies as visual testament to the massacre. The work of this initial group saw the preservation of over 800 bodies displayed in 24 classrooms of the never completed Polytechnic. In the main building is the exhibition centre, and in the smaller schoolhouse buildings are the 24 classrooms where the bodies lie across racks (Eltringham, 2014). These bodies have been preserved with lime - their dried skin clings tightly to the bones: the hair remains attached, and many bodies still wear the clothes from the day of the massacre.

Thinking and writing about genocide, Audrey Small (2007) states, 'should be an attempt to explore and comprehend humanity's attempt to comprehend' (p. 98). Memorial sites of mass atrocities exhibit difficult subject matter, especially when these sites house human remains as proof of a committed atrocity. In this article, I explore how the labour involved in creating and maintaining memorial spaces might offer insights into the production of commemorative sites involving human remains. ${ }^{4}$ In so doing, I hope to provoke discussion on the pedagogical function of human remains as a guide in reflection around the human capacity for extreme violence. Key to this reflection is the conceptual role of care and its specificity within Murambi. This article does not seek to investigate the responses or understandings of visitors to memorial sites 
of mass atrocities. Rather, I focus on the production instead of the consumption of memorial spaces and the meaning that is cultivated from this labour. This research stems from the site visits and semi-structured interviews I conducted with Murambi's employees in 2012.

I begin by discussing Murambi in relation to other genocide memorial sites both nationally and internationally. I then move to discuss Rwanda's official commemorative narrative in relation to Murambi. After, I examine some of the existing scholarship on care, comparing and contrasting it to the care that occurs at Murambi. Following this discussion, I introduce to the reader the theoretical framework of the Labour of Care, which provides a basis to reflect upon human remains in relation to humanity's capacity for mass violence.

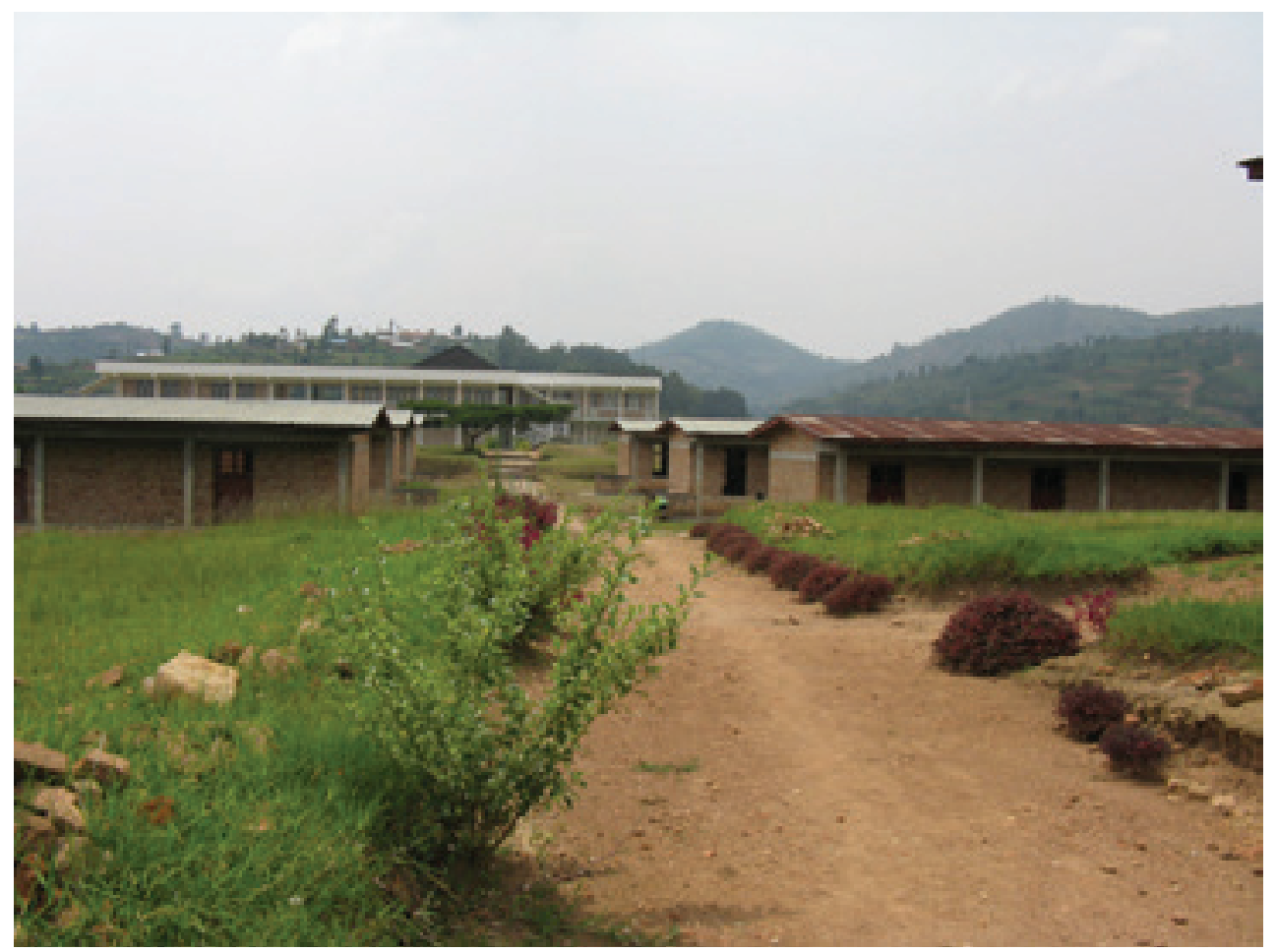

View from the back of the Murambi Genocide Memorial. In the foreground are the bungalow-style classrooms, which house the 800 bodies, in the background is the former Polytechnic school that now houses the Murambi's exhibition centre. Photo taken by the author, January 2012.

The Murambi Memorial is one of six Rwandese national genocide memorial sites. This means its care and maintenance falls under the purview of the National Commission For The FightAgainst Genocide (CNLG) created by Rwandan Parliament in 2007. ${ }^{5}$ Prior to the CNLG, the creation and maintenance of genocide memorials was a decentralized phenomenon (Meierhenrich, 2009). At that time, the care of Rwanda's memorials fell primarily under the authority of the district and sector levels of government.

In 2012, I visited five out of the six national sites where I encountered various approaches to display human remains. At Nyamata, the bones and skulls are in deep crypts. While visiting, a memorial guide led me inside these giant tombs that contained ceiling to floor shelves stacked with bones and skulls sorted by body part. At Nyamabuye and Bisesero, the bones and skulls are under tarps, on wooden racks, or in separate metal sheds. ${ }^{6}$ The Kigali Memorial Centre is a multi-level exhibition space. Outside, this site houses several mass graves set amidst its well-tended gardens. While human remain are present here, they remain in the sealed graves and they are not visible to visitors. Murambi shares in all of these display strategies mentioned 
above-bones and skulls arranged in glass display cases, sorted bones piled on wooden shelves as well as sealed mass graves (DeMartini, 2012; Meierhenrich, 2011; Williams, 2008; Caplan, 2007). Even internationally, Murambi shares characteristics with genocide memorial sites, such as the Choeung Ek Genocidal Center and Tuol Sleng site in Cambodia as well as the Holocaust Memorial in the former Nazi extermination camp at Auschwitz.

Similar to the arrangement of human remains at Rwanda's national genocide memorials, Scion (2011) discusses the aestheticization of human remains at Choeung Ek: the skulls and bones of victims are stacked in a structure almost 62 meters high or arranged in wooden cases. At Tuol Sleng, the memorial once displayed a map of Cambodia made up of skulls, but as of 2002, it was removed and replaced with a photograph of the map (Williams, 2004; Ledgerwood, 1997). Regarding Auschwitz, Jacobs (2008) describes the display of human hair as the most 'visually compelling and emotionally charged' artefact in the installation (p. 221). Myers (2011) too remarks on the significance of human hair at Auschwitz, noting that the hair has become a foci for small offerings to the memory of the victims. And while to some degree Murambi aestheticizes human remains, it differs from these other sites because it displays wholly intact human bodies: intentionally preserved this way by the massacre's survivors (Raymont \& Basmajian, 2009; Sodaro, 2011; lbreck, 2011).

When visitors arrive at Murambi, they are paired with a guide-whether or not this is mandatory is unclear. According to several guides, they receive some psychological and tour guide training, but the duration of these programmes was never mentioned. A tour begins in the exhibition hall where the guide invites visitors to make their way through information panels while they stand nearby to answer questions. Leaving the exhibition hall, visitors walk towards the classrooms across the compound's gardens. Sprawling green hills surround Murambi. There are several shade-giving acacia trees placed close to the pathway where richly coloured flowerbeds align its edges.

Entering into the first classroom, a visitor encounters over thirty, bleached-white bodies laid across the tables. The guide waits outside until visitors return back outside. During my first visit, our guide explained some of the reasons why the bodies lie in certain ways, where some of these bodies were found, and how you could tell how they died. A lot of these bodies lie with their arms covering vulnerable parts-stomachs, faces, and genitals. Significant to understanding these bodies in relation to the memorial site within Rwanda is the official commemorative narrative that frames all of the national sites.

\section{Rwanda's official commemorative narrative}

Some scholars have critiqued Rwanda's official commemorative narrative for imposing a singular political understanding on the 1994 event (Buckley-Zistel, 2009; Zorbas; 2009; King, 2009; Hintjens, 2008; Pottier, 2002). In the wake of a highly divisive history, a part of the commemorative framework includes nation-building rhetoric that hinges on notions of sameness; for example, the government's popular dictate, 'We Are All Rwandans Now' (Grant, 2010). Furthermore, the current government attempts to remedy these divisions by rewriting the pre-colonial era as a time without strife (Buckley-Zistel, 2006). That way, political officials can call for a unified future because they can argue that Rwandese society has already experienced such harmony.

The government faces a complex task of rebuilding a nation ripped apart by a civil war in the early 1990s, which was crippled again by the 1994 genocide. However, this attempt to 'gloss over' the pre-colonial complexities is also problematic for the study of history. Both Jefremovas (1997) and King (2009) argue that group identities in the precolonial era were fraught with social differences and competing interests. Moreover, this pre-colonial rationalization ignores the complex set of tensions leading up to, and immediately after, the 1994 genocide (DeMartini, 2012). For example, the 1990 Rwanda Patriotic Front's (RPF) invasion of Rwanda from Uganda (this paramilitary group, with the current President Kagame at its leadership helm, would eventually become Rwanda's governing party) arguably intensified the racialized Hutu propaganda against Tutsi; the massacres against the Hutu in neighboring Burundi as well as the post-genocide reprisal killings of Hutu, by the RPF, in the refugee camps in the Democratic Republic of the (Buckley-Zistel, 2006; Edmondson, 2009). Thus, the government's current efforts to construct a unified past raises concern over who this nationalist narrative represents. 
Hintjens (2008) argues that the genocide survivor experience is central to the current government's vision of Rwanda's national identity. In the past, Rwandese with mixed ancestry (Hutu-Tutsi parents) have been unable to claim survivor status (Hintjens, 2008, p. 31). ${ }^{7}$ In addition, I spoke with several Rwandese who stated that during the national week of commemoration they leave the country because this part of Rwandese identity does not include them. As Tutsi born outside Rwanda, these individuals returned to Rwanda after the genocide. For them, the survivor storyline is not a part of their Rwandan identity. The idea of the genocide 'survivor' weaves itself throughout official narratives of nationhood. Those who do not share in this highly regarded national experience feel estranged from its prominence within the nation's post-genocide identity. Although the government officially promotes a national identity based on 'sameness,' the reality of these nation-building strategies suggests otherwise. Rwanda's national identity seems increasingly premised upon the Tutsi experience of the genocide, which appears to stand for the common experience of the nation.

This centralization of the Tutsi experience frames Rwanda's official commemorative narrative, which defines the storyline at Rwanda's national memorial sites. While the narrative framing Murambi is no exception, the opportunity to speak with various professionals linked to the memorial site affords a space to reflect beyond the government's streamlined model. Their experiences and relationship to the site creates new avenues to think, reflect, contest, and teach about the remnants of genocide. In addition, these openings afford one the opportunity to inquire further into the constellation of memory, place, and the (re)production of meaning.

To pursue this inquiry, I introduce the concept of the labour of care. This concept concerns how the maintenance of space and meaning at Murambi provides a basis to reflect on the display of human remains and their function at this site. I look at some of the varying ways that previous thinkers have mobilized the concept of care. Then, I demonstrate how the labour of care diverges from these existing discussions. I spend the remainder of this paper developing this concept, demonstrating how it emerges from the specificity of the Murambi Memorial site, and more broadly, how it offers a means to think about the production of memorial sites that exhibit human remains to commemorate mass atrocities.

\section{Care as a Conceptual Framework}

The concept of care has a wide breadth of meaning and functions. A rich field of academic literature engages the notion of care, and I have provided only a snapshot of its conceptual terrain. First, I examine how scholars have worked with this notion in relation to labour and the living. Second, I discuss care with regards to human remains across the museum studies and forensic anthropology disciplines. In so doing, I seek to better understand the production of care and labour in relation to the efforts of Murambi's survivors to create a space to preserve and display the victims' remains.

Discourses around care, argues James (1992), range from the tender nurture of parents with their newborn child to the institutionalized containment of the elderly and people living with mental health problems. Gordon (1991) views care more broadly as a 'fundamental human imperative' (p. 45), whereas Staden (1997) sees this concept as 'culturally and politically shaped' (p. 148). Nel Noddings (1984) pioneered theoretical notions of contemporary care. She developed an ethics around the relationality of care, which help to foreground the sociopolitical contexts in which caring occurred. James (1992) defines the role of care through an analytical lens of labour. The carer is someone who gives, 'sustained, close, direct mental and physical attention to the person being cared for' ( $p .489$ ). On these terms, labour becomes an intricate part of the social relationships involved with care. Emotional labour, too, is another central aspect of care. Emotional labour frames how labourers respond to the cared-for in a personal manner (Hochschild, 1983). Like its physical counterpart, the emotional labour in care responds to the day-to-day needs of another. While these notions of care provide some theoretical parameters to discuss the production of care and labour at Murambi, we must also consider the breadth of scholarship that pertains to care for the dead, particularly human remains. In the following section, I focus on some literature pertaining to the care and management of the actual remains within institutional settings (Stocking, 1985; Cassman, Odegaard, and Powell, 2008; Giesen, 2013). 


\section{Human remains within institutions and the question of care}

As indigenous groups actively influence policy around sacred objects and human remains (Giesen \& White, 2013; Jacobs, 2009; Gallagher, 2010; Nash, 2010), there is also a shift in museological and curatorial practices to emphasize the preservation of a collection's integrity in its 'natural unaltered state' (Odegaard \& Cassman, 2008, p. 77). This kind of thinking encounters a range of tensions, especially when confronted with questions around the cleaning of human remains: a process considered ultimately invasive. For Giesen and White (2013), how institutions handle human remains varies internationally. At the core of these variations are different social and legal perspectives revolving around one central question, 'what are human remains' (p. 13)? For example, what is the individual's or group's proximity to these remains? Are they direct descendants, distant ancestors, enemy combatants? Thinking about human remains and their prominence in the minds of the living, situates them as evocative entities of material culture.

Stocking (1985) defined material culture as, 'objects of others' (p. 4), items that come from the past. However, human remains are not simply material objects as evidenced by the literature concerning appropriate terminology (Cassman, Odegaard, Powell, 2008; Sprague, 2005) - and is a tension I address later in this article. The types of care that occur within collections of human remains depend on the institution: university, medical, and/or museums (Woodhead, 2013). Regardless of where the remains are kept, Cassman and Odegaard (2008) argue that the curation and care of human remains should occur within an ethical framework of propriety and reverence; that is, a deep sense of respect is necessary for these objects in both the spaces that house them and their practices of care.

The care of human remains also extends to funerary practices. In Pomuch, a Mayan town in Mexico, many family members visit the local cemetery during the Day-of-the-Dead celebrations to clean the bones of their deceased, place flowers and new embroidered cloths alongside the remains (Brosnan, 2006). According to one practitioner, cleaning the bones of one's deceased relatives reminds the souls of the dead that they are not forgotten among the living (Adams, 2004; Odegaard \& Cassman, 2008). Care, in this context, concerns how the living renews connections with the dead. In Tanzania, care for the dead among some Muslim communities concern how the living ensures the well-being of the deceased in their passage from earth to heaven (Becker, 2009). Here, care for the dead focuses on the voyage of the deceased from their earthly bodies to their divine destinations.

The care and labour that occurs around the human remains at Murambi encompasses many of the aspects touched upon in the above literature: displayed in an institutional setting (the national memorial site), invasive cleaning procedures for preservation, and as I will demonstrate soon, possesses a tenderness similarly shown by the communities in Mexico and Tanzania. However, the human remains at the Murambi Memorial have not undergone funerary rites: most of them cannot be identified. In Rwanda, the question of 'when' the remains will be buried remains a controversial topic, as does the government's interest in their memorialization. According to one memorial professional and former survivor, Luc, the display of human remains is a political opportunity for the government to mobilize support based on survivors' anxieties of possessing 'authentic' proof of the genocide (DeMartini, 2012). Luc states:

The first survivor I met [at Murambi] I ask him, what do you want to do with this? Do you want to keep this? He says, "look" (and we're talking in Kinyarwanda)... he says, "look, if we bury, we forget." He says, "burying equals forgetting... that's what it is for us." The people, the guys who are called AMAGAJU... they were the survivors of Murambi, there the ones, back in time, where RPF was non-existent [as a governing body], who retrieved the bodies from the shallow mass graves, washed them, took off their clothes and put on the lime, they used the lime... as it happened, one of them was a guy who did bio-chemistry or something, who trained, who knew that lime could preserve things, it does preserve but it does destroy as well, so they came up with this idea, and they did it, so this government actually never preserved these bodies. Only now it's trying too, for the first time after 17 years. (DeMartini, 2012: 89) 
Echoing Luc's sentiments, Ibreck (2010) notes that, for critics, the display of bones and human remains is evidence of the dominant influence of RPF's narratives and politics within the country's memorialization practices. Moreover, the debate over burial involves all sectors of Rwandan society. Ibreck observes that many Rwandese-although not specifying whether participants were from Murambi or not-felt the display of bones to be traumatic and in need of resolution. Others felt that immediate reburial was not the solution, as the bones, displayed at memorials still retained purpose.

Whether or not the bodies should be buried or displayed is not an argument this paper makes. Rather, I reflect on the subject matter as is, which happens to be that currently the bodies are displayed. Thus, for the purposes of care-based labour in the context of memorials, one might ask, what is the purpose of this care in relation to the human remains on display? In such a context, I suggest that the caring creates a space to consider what the survivors intended to achieve by preserving the bodies, and by extension, what might the various visitors take away from this site. In so doing, the significance of the remains becomes the starting point to attempt an intelligible relationship with their unsettling presence.

\section{The Labour in the Labour of Care}

The labour of care is both performative and conceptual; performative in terms of how the work carried out at the memorial infuses, maintains, and renews Murambi's space, and conceptual with regards to how the care embodies daily work-related tasks. For example, Jean, both a site caretaker and a survivor of the Murambi massacre, understands her work through an attentive obligation-while she tends to the bodies in the classrooms, she feels as though she renews the connection to the memory of her husband and children, whom she lost there. The Hutu militias spared her life because she is a Hutu, but killed her family because her husband was a Tutsi.

Murambi's spaces stage a site where Jean can conceptualize her family's absence through some of the daily tasks of her employment. Professionally, Jean's responsibilities include cleaning the classrooms that house the bodies and ensuring that the bodies remain clean (free from insects or mould). These tasks require Jean to inspect both the classrooms and the bodies daily, washing the bodies with soap and water when needed as well as identifying what bodies require further preservation. In the past, preservation work included the application of lime, which usually took up to three weeks to tend to all the bodies in need of care at the site (DeMartini, 2012).

Jean works under the direction of Langston, a memorial professional, who works nationally to preserve Rwanda's commemorative sites. Langston also describes his work in terms of obligation, particularly as a service to the memory of his family whom he lost to the genocidal killings at Nyamata. Below, he describes his relationship to Murambi, which captures how he understands his work as both a memorial professional and former survivor:

Langston: I know Murambi for many years, I visited many times in order to observe and have more information about Murambi [...] Then after, I hear that they wanted someone to look after the different memorials, and then I started several years back, working with the preservation, conservation using different product, chemical products.... I worked with the national museum to preserve the human bodies, bones, skulls and the other artefacts that are found across the country. The motivation was that as a survivor of genocide, I wished to participate in keeping the memory and preserving the genocide proof. (DeMartini, 2012: 79)

After ending the recorded portion of the interview, I waited to see if he wanted to say anything more to this aspect of his life. When I realized he finished, I asked how he handled this aspect of his work, that is, to work in proximity with the bones and bodies at memorials while being a survivor himself. Langston chuckled nervously, biting his lower lip. He stared off into space and answered, 'I don't know... it's very difficult to clean and wash the bodies' (DeMartini, 2012: 90).

Variables of renewal and service frame the personal memorial practices of Jean and Langston. They view their responsibilities to the past in accordance to the varying experiences that led them to commemorative work. Both Jean and Langston discuss an obligation to their family's memory, which defines a part of their relationship to the memorial's space. 
Summarizing their work outlines the processes of place-making, which 'mediate and construct social memory and identity by localizing personal emotions and defining social relations to the past' (Till, 2005, p. 8). Practices of place-making, Till argues, concern how people memorialize space, create and attach narratives to them, and seek the renewal of its space through a certain point-of-view.

Murambi's existence, the renewal of its memory, depends upon the work of the employees such as Jean. This work can include: tending to the gardens, keeping the lawns manicured, neatly stacking the victim's clothes on shelves for display, inspecting the bodies for insects, washing them, and guiding visitors through the exhibition and site's grounds. From these tasks, Murambi's space stages a performance that connects the past to the present through the repetitive and attentive actions of labour, renewing the memorial site's memory. Place-making is not a finite act, but rather, an ongoing occurrence. The work of Murambi's employees cultivates its meaning and identity through the processes of place-making, revealing how the endeavour of labour, performed within the memorial, ultimately sustains its memory.

Having now discussed what the labour consists of at Murambi, an important distinction needs to be made between the caring labour at Murambi and the notions of care reviewed earlier in the section, 'Care as a conceptual framework.' While the varying conceptions of care examined in this earlier section share in the emotional and physical aspects of the labour that occurs at the Murambi Memorial, these notions concern care for the living. The caring labour that occurs at Murambi is premised upon the care of human remains. Nodding (1984) states, 'when my caring is directed to living things, I must consider their natures, ways of life, needs and desires... I try to apprehend the reality of the other' (14). However, caring for human remains precludes an understanding of the reality of these others. The carer cannot understand what the one in need of care may feel, which for Noddings (1984) is an essential part of her ethical framework. With this distinction in mind, I move forward to develop a conception of care specific to the labour occurring at Murambi.

\section{The Care in the Labour of Care}

The second component in the labour of care is the aspect of care. To speak of the latter aspect, I discuss first the objects that are being cared for as well as how they are made to become objects of significance. Tamen (2001), who examines the functions of interpretation within the fields of art, history and law, makes three general claims about the capacity of interpretation in relation to an object. First, the object becomes interpretable when surrounded by groups that share an interest in the object. Second, the object's interpretability hinges upon these groups bestowing upon it its interpretable qualities. Third, Tamen describes a 'society of friends,' not in the usual notion of friendship, but more along the lines of common grounds between different people. I think of Tamen's 'society of friends' in relation to what Roger Simon (2006) describes as 'memorial kinships'. These kinships are groups of individuals formed by their attentiveness to a set of material remnants through their diverse concerns that arise from each person's varying standpoint. The coming together of individuals from diverse standpoints around certain remnants creates a space to discuss, contest, and renew a remnant's significance.

With regards to the display of human remains at Murambi, what qualities make them interpretable? In the contested space of Murambi, what common ground stands to create a 'society of friends'? The criterion is the occurrence of genocide; the bodies retain a recognizable significance because of the visible consequences of violence against them. Previously mentioned, sentiments towards Murambi in Rwanda range broadly from disgust and uneasy curiosity to support and indifference. The groups that gather around Murambi often disagree, but all of them recognize the significance of the site, its spaces, and the material remnants that connect the past to the present.

Through the labour of Murambi's employees, involved in its design and maintenance, the memorial obtains its interpretable qualities. That is, the employees' labour set the parameters of interpretation, or at least, a set of parameters intended to tell a particular story. In the process, their ongoing work permits for groups of individuals to form in order to reflect, think, and debate on the significance of Murambi's displays. At the same time, the care occurs from a co-constitutive process: from the employees' work and the gathering of groups with interest 
in the site. The care also takes on curatorial qualities. The work of Murambi's initial survivors, who returned to the school grounds after the massacre, excavated the bodies and selected the ones best to display, there exists in their action a desire to make intelligible to the world the story of their trauma. These actions were conscious attempts to make remnants perforated by violence, interpretable.

Lehrer and Milton (2011) define curation in accordance with its root meaning, 'to care for' (p. 4). By returning to its root meaning, they argue, permits for discussions in curation and museums to expand to include heritage sites, memorials, and even virtual spaces. Individuals, who create and maintain such places, are also the individuals who care for the past through the arrangement and ordering of a given space (Lehrer and Milton, 2011). On these terms, curating as an act of caretaking offers a productive means to engage the initial work of Murambi's survivors as well as those who maintain the space, tend to the bodies, oversee preservation, and lead visitors through the site.

According to Tamen's (2001) understanding of how interpretations emerge around an object, the memorial guides plays a crucial role in maintaining the memorial site's interpretable qualities. Without the ongoing renewal of memory through the daily tasks of preservation, Murambi's employees have suggested that the site runs a risk of becoming obsolete. However, there is a necessary revision that I make to Tamen's work in relation to Murambi. That is, can bodies ever be spoken of as simply material objects? Keenan and Weizman (2012) suggest that, "human remains are the kind of objects from which the trace of the subject cannot be fully removed' (12). On these grounds, Tamen's (2001) initial claims about the object in relation to the functions of interpretation must be expanded in order to differentiate between the meaning of human remains as objects and art objects such as a bronze statute. Human remains on display need to be understood as objects that were once subjects.

The transformation from animate to inanimate, the violence that demarcates the space between these two states, is what makes human remains rendered through violence unique and unconventional objects. In this way, thinking about human remains as subjects-come-objects might be more beneficial to do so through the framework created by Keenan and Weizman (2012). For these two scholars, a turn to forensics permits the object to narrate its experiences as a subject through the contours, crevices, and cracks that appear on its bones. This is what forensic scientist, Clyde Snow, termed 'osteobiography,' which is the study and identification of human remains. Snow states, 'the bones, no longer the living human but not simply an object, bear the imprint of a lived life' (quoted in Keenan and Weizan, p. 17). Snow's statement, for Keenan and Weizman, connects to their own theoretical considerations of the forensic work surrounding the identification of Josef Mengele's skull. Mengele was a high-ranking official within the Nazi regime who escaped to Brazil, eluding any criminal trial for his collaboration in war crimes during WWII.

The turn to forensic work, outlined above, reminds me of one of the primary tasks of Murambi's memorial guide, which is to mediate between visitor's and the human remains on display. The term 'mediator' in the realm of forensics relates to the role forensics scientists played while identifying Mengele's skull and communicating their findings with interested groups - these groups were described as the 'forum,' which in terms of Mengele's skull were primarily Holocaust survivor groups (Keenan and Weizman, 2011). Similarly, these terms aptly apply to both the work of memorial guides (the mediators) as they try to make knowable the events of Murambi through the objects on display, and the various groups of memorial visitors (the forum) ${ }^{8}$

Recalling my first visit to Murambi, I remember how the memorial guide led me to a room where dozens of skulls lay neatly arranged in glass-enclosed cases. In this room, he began to tell a story of their transformation from subject-to-object. He led me over to each case, pointing to the different skulls and identifying how each person died. A blunt object, such as a hoe, likely caused a large hole. A small, circular hole depicts where a bullet entered the skull, and the long cracks that snake across the surface of the cranium indicate where the victim's head had been smashed. In a way, these holes and cracks represent the pivotal moment when the subject became the object. This practice of interpreting these objects in relation to their holes occurred at every memorial site that I visited. Through these encounters arise the inseparable aspect of care, providing a context for both the mediator and forum to recognize 
the residual traces of the subject. In telling these stories, in mediating between the objects and the forum, the care in the Labour of Care situates itself within the precarious in-between that demarcates the boundary between the subject and object. ${ }^{9}$

To a great extent, the mediator's interpretation of the displayed objects occurs with personal biases by experiences that have shaped her personal worldview. Yet, the guide's role as a mediator is integral to creating a basis for a forum, assisting in the processes that try to make intelligible the story of Murambi's subjects-come-objects-details not shared by the display themselves. A tenderness for these objects arises from the mediator's and the forum's recognition of the residual traces of the subject in the object. This is an integral component in the consideration of care in the labour of care.

One criticism that Murambi has faced is the suggestion that, in its current display of bodies, visitors only learn the story of their death instead of a story of their lives (DeMartini, 2012). Understandably, lives lost to violence should be celebrated in the lived moments that can be remembered. However, when society faces its violent acts, something else emerges; which is, the troubling reflection that every human being has the capacity to commit great acts of violence. These unsettling aspects of humans beings are often ignored within established discussions on the topic. Todd (2009) argues that if claims about humanity remain universal and unchanging than we, 'risk an abstraction that seems to live a life of its own... precepts that have little to do with ongoing human communicative practices' (p. 152). Although Todd (2009) makes this argument in a critique of cosmopolitanism and education, she also touches on an agonizing part of encountering human remains: we are confronted with the otherness of being human. ${ }^{10}$

Indeed, 'there is something unsettlingly human about that violence which we live withalbeit against our will' (Todd, 2009, p. 1). In the case of Murambi, the remains of the forcefully deceased, their display, confronts us with the violence that is human. Prevailing discourses on humanity, suggests Todd, tend to rely too heavily on utopic values of goodness, abandoning imperfection from its definition. Thus, notions of imperfection become linked to inhumane attributes, which minimizes the likeliness for critical discussions to occur on the relationship between humans and violence (Todd, 2009). The likeliness of these conversations occurring become further minimized when violent acts are accompanied by conversations of incredulityas though such acts of violence are separate from being human. Todd's (2009) work offers an in-depth means to encounter the bodies displayed at Murambi. Her thinking provides an avenue to include not only the knee-jerk emotional reactions, but also, sustained reflections on the question of human beings and their capacity for violence. However, the memorial site's current commemorative framework provides little room to speak about the unbearable and horrifying attributes of being human. This is due to the redemptive promise of 'Never Again' that appeases, albeit only at a surface-level, society's need to critically examine the roots of a conflict.

When notions of humanity fail to include its imperfections, the complex choice individuals and societies face during times of genocidal violence become obscured, and so do opportunities to better understand the function of violence within these moments. The presence of bodies at Murambi stages an occasion to critically discuss the violent characteristics of human beings otherwise dismissed in conventional commemorative frameworks such as 'Never Again'. The human remains, the preserved bodies of Murambi's massacre present a possibility to the forum to take away deeply transformative reflections on the state of humanity, and perhaps, elicit others to join and debate in these difficult conversations.

Framing the work of Murambi through the lens of the labour of care provides a generative avenue to consider the work of caretaking at Murambi, specifically around the recognition of human remains as subjects-come-objects. This perspective highlights the need for interpretation that includes an understanding for the distinctiveness that human remains present as objects of display within genocide memorials. While this article only alluded to better understandings of the human capacity for violence, it primary aim was to offer ways to attempt an intelligible relationship with seemingly incomprehensible acts. The meaning of Murambi derives from its mediators and their forum; that is, the coming together of the employees, their labour, visitors both local and global, as well as the academic and professional community who look to sites like Murambi as a place to meaningfully engage with lessons from the recent past.

Submitted: 13 June 2014

Finally accepted: 3 November 2015 


\section{Acknowledgements}

I would like to thank Mario Di Paolantonio and Warren Crichlow of York University for their thoughtful supervision and guidance in developing the concept, Labour of Care. I am grateful to Ariane Zaytzeff, Julia Viebach, and Omar Rugwiro for sharing their expertise knowledge about Rwanda. I am also thankful to Bronwen Low of McGill University for her support as well as Kate Hill from the editorial board at Museum and Society for her professional guidance and constructive feedback.

\section{Notes}

1 This article attempts to further develop the concept of the Labour of Care, which first appeared in DeMartini, A. (2012). Learning to think with the incomprehensible: Human remains, the Murambi Memorial and the intimacy of personal memorial practices. (Order No. MS00013, York University (Canada)). ProQuest Dissertations and Theses, 129. Retrieved from http://search.proquest.com/docview/1509922972?accountid=12339. (1509922972).

2 Hutu moderates are individuals who refused to participate in the 1994 genocidal killings.

3 It is important to note that numbers around the official death toll fluctuate. I encountered estimates as high as 50,000 provided by some of the employees at Murambi as well as other scholars- see Eltringham (2014). My point is not to fixate on numbers, but rather, to show that even 'facts' are subject to interpretation.

4 A 'memorial visitor' varies greatly from Rwandese born outside the country, former survivors, primary and high school Rwandese students as well as the international community. However, many of the employees working at Murambi acknowledge that this site is primarily geared for an international audience- mostly, Westerners.

5 For more information about the organizational structure and responsibilities of CNLG see: http://www.cnlg.gov.rw/

$6 \quad$ At Nyamabuye, the bodies under tarps had been found recently in the last year as work crews dug up old latrines.

7 Hintjens (2008) states that the ethnicity of one's father would determine the survival of his children during the genocide, and afterwards, the ability of his children to claim survivor status post-genocide (31). For example, if one's father were a Tutsi, then he and the children would likely be targeted, and possibly the Hutu mother would be spared. In post-genocide Rwanda, if your father were a Hutu and your mother were a Tutsi, it was unlikely that you could claim survivor status.

8 To reiterate, Rwandese visitors vary greatly from Rwandese born outside the country, to former survivors, to primary and high school Rwandese students in addition to the visitors from the international community.

9 Parts of this paragraph previously appeared in DeMartini, A. (2012). Learning to think with the incomprehensible: Human remains, the Murambi Memorial and the intimacy of personal memorial practices. (Order No. MS00013, York University (Canada)). ProQuest Dissertations and Theses, 129. Retrieved from http://search. proquest. com/docview/1509922972?accountid=12339. (1509922972).

10 'bid. 


\section{References}

Adams, L. J. (2004, October 31). Mexican Indians clean exhumed bones to welcome spirits of the departed. St. Augustine Record. Retrieved May 20, 2014 from http:// staugustine.com/stories/103104/wor 2674873.shtml

Becker, F. (2009). 'Islamic reform and historical change in the care of the dead: Conflicts over funerary practice among Tanzanian Muslims' Africa: The Journal of the International African Institute, 79(3), 416-434

Brosnan, G. (2006, October 30). 'Mayans bring out dead in intimate graveyard rite' Reuters UK. Retrieved June 10, 2014, from http://uk.reuters.com/article/2006/11/01/oukoeuk-life-mexico-bones-idUKN3039913020061101

Buckley-Zistel, S. (2009). 'Nation, narration, unification? The politics of history teaching after the Rwandan genocide'. Journal of Genocide Research, 11(1), 31-53

Caplan, P. (2007). 'Never Again': Genocide Memorials In Rwanda. Anthropology Today, 23 (1), 20-22

Cassman, V., \& Odegaard, N. (2008). 'Treatment and Invasive Actions' In V. Cassman, N. Odegaard \& J. Powell (Eds.), Human Remains: Guide for Museums and Academic Institutions, 77-96, New York: Rowman \& Littlefield

Cassman, V., Odegaard, N., \& Powell, J. (Eds). (2008). Human Remains: Guide for Museums and Academic Institutions. New York: Rowman \& Littlefield

DeMartini, A. (2012). Learning to think with the incomprehensible: Human remains, the Murambi Memorial and the intimacy of personal memorial practices. (Order No. MS00013, York University (Canada)). ProQuest Dissertations and Theses,129. Retrieved May 10, 2014, from http://search.proquest.com/ docview/1509922972? accountid=12339 (1509922972).

Duffy, M. (2005). Reproducing Labor Inequalities Challenges for Feminists Conceptualizing Care at the Intersections of Gender, Race, and Class. Gender \& Society, 19(1), 6682

Duffy, M. (2011). Making care count: A century of gender, race, and paid care work. Rutgers University Press.

Dwyer, R. E. (2013). 'The Care Economy? Gender, Economic Restructuring, and Job Polarization in the US Labor Market.' American Sociological Review, 78(3), 390-416

Eltringham, N. (2014) 'Bodies of evidence: Remembering the Rwandan Genocide at Murambi' in N. Eltringham and P. Maclean (Eds.) Remembering Genocide 200-219, London: Routledge

Fischel, J.R. (2006). 'Genocide In Rwanda' The Virginia Quarterly Review, 82 (1), 263

Gallagher, S. (2010). 'Museums and the return of human remains: An equitable solution?'

International Journal of Cultural Property, 17(1), 65-86. doi:http://dx.doi.org/10.1017/ S0940739110000019

Giesen, M. \& White, L. (2013). 'International Perspectives towards Human Remains Curation.' In M. Giesen (Ed.), Curating human remains: Caring for the dead in the United Kingdom, 13-24, Woodbridge, Suffolk, UK: Boydell Press 
Giesen, M. (2013). Curating human remains: Caring for the dead in the United Kingdom. Woodbridge, Suffolk, UK: Boydell Press

Gordon, S. (1991). 'Fear of Caring: The feminist paradox' American Journal of Nursing, 91(2), 45-48.

Graham, H. (1983). 'Caring: A Labour of Love.' In Finch, J., \& Groves, D. A Labour of love: Women, work, and caring. London: Routledge \& K. Paul.

Guyer, S. (2009). 'Rwanda's bones' Boundary 2, 36(2), 155-175

Hintjens, H. (2008). 'Post-genocide Identity Politics in Rwanda' Ethnicities, 8(1), 5-41

Hochschild, A. (1983). The Managed Heart: Commercialization of Human Feeling. Berkeley: University of California Press

Ibreck, R. (2010). 'The politics of mourning: Survivor contributions to memorials in postgenocide Rwanda' Memory Studies, 3, 4, 330-343

Jacobs, J. (2009). 'Repatriation and the reconstruction of identity' Museum Anthropology, 32(2), 83-98

Jacobs, J. (2008). 'Gender and collective memory: Women and representation at Auschwitz' Memory Studies, 1(2), 211-225

James, N. (1992). 'Care= organization + physical labour + emotional labour' Sociology of Health and IIIness, 14(4), 448- 509

Keenan, T \& Weizman, E. (2011). 'Mengele's Skull' Cabinet, 43

Keenan, T \& Weizman, E. (2012). Mengele's Skull: The Advent of Forensic Aesthetics. Berlin: Sternberg Press

Kigali Memorial Centre (n/d). 'Murambi Memorial Centre' Retrieved March 2, 2012, http:// www.kigaligenocidememorial.org/old/centre/other/murambi.html

King, E. (2009). 'From Data Problems to Data Points: Challenges and Opportunities of Research in Postgenocide Rwanda' African Studies Review, 52(3), 127-148

Ledgerwood, J., 'The Cambodian Tuol Sleng Museum of Genocidal Crimes: National Narrative,' Museum Anthropology 21, (1) (1997), 82-98

Lehrer, E \& Milton, C. E \& Patterson M.E (2011). 'Witnesses To Witnessing'. In Curating Difficult Knowledge: Violent Pasts In Public Spaces. UK: Palgrave MacMillan

Meierhenrich, J. (2011) 'Topographies of remembering and forgetting: the transformation of Lieux de Mémoire in Rwanda', In Straus, Scott and Waldorf, Lars, (eds.) Remaking Rwanda: State Building and Human Rights After Mass Violence 283-296, Wisconsin, USA: University of Wisconsin Press

Meierhenrich, J. (2009) 'The Transformation Of Lieux De Mémoire: The Nyabarongo River in Rwanda, 1992-2009' Anthropology Today, 25(5), 13-19

Myers, A. (2011). 'The things of Auschwitz' In [add in editors/authors here], Archaeologies of Internment, 75-88, Springer New York

Nash, S. E. (2010). 'NAGPRA after two decades' Museum Anthropology, 33(2), 99-104 
Noddings, N. (1984). Caring, a feminine approach to ethics \& moral education. Berkeley: University of California Press

Peters, A.H, Cassman, V. \& Gustasson, M. (2008). 'Associated Artifacts', In V. Cassman, N. Odegaard \& J. Powell (Eds.), Human Remains: Guide for Museums and Academic Institutions, 129-148, New York: Rowman \& Littlefield

Pottier, J. (2002). Reclaiming Rwanda: Conflict, Survival and Disinformation in the Late

Twentieth Century. United Kingdom: Cambridge University Press

Raymont, P. \& Basmajian, S. (Producers). (2009). 'Triage: Dr. Orbinski's Humanitarian Dilemma' [DVD] Toronto: Mongrel Media and National Film Board Of Canada

Scion, B. (2011). 'Conflicting sites of memory in post-genocide Cambodia' Humanity: An International Journal of Human Rights, Humanitarianism, and Development, 2(1), $1-21$

Simon. I. R. (2006). 'The Terrible Gift: Museums And The Possibility Of Hope Without Consolation', Museum Management And Curatorship, 21(3), 187-204

Small, A. (2007). 'The Duty of Voices: A Solidarity of Voices After the Rwandan Genocide' Paragraph, 30(1), 85-100

Sodaro, A. (2011). 'Politics of the Past: Remembering the Rwandan Genocide at the Kigali Memorial Centre', In E. Lehrer, C.E. Milton, and M. E. Patterson (Eds.) Curating Difficult Knowledge: Violent pasts in public places, 71-90, London, UK: Palgrave MacMillan

Staden, H. (1998). 'Alertness to the needs of others: A study of the emotional labour of caring' Journal of Advanced Nursing, 27, 147-156

Sprague, R. (2005). Burial terminology: A guide for researchers. Rowman Altamira

Stocking, G. W. (1985). Objects and others: Essays on museums and material culture. Madison, Wis: University of Wisconsin Press

Tamen, M. (2001). Friends of Interpretable Objects. Cambridge, MA: Harvard University Press

Till, K. (2005). The New Berlin: Memory, Politics, Place. Minneapolis: University of Minnesota Press

Williams, P. (2008). Memorial Museums: The Global Rush To Commemorate Atrocities. Oxford, U.K: Berg Publishers

Williams, P. (2004). 'Witnessing genocide: vigilance and remembrance at Tuol Sleng and Choeung Ek. Holocaust and Genocide Studies, 18(2), 234-254

Woodhead, C. (2013). 'Dealings with the Dead: A Personal Consideration of the Ongoing Human Remains Debate' In M. Giesen (Ed.), Curating human remains: Caring for the dead in the United Kingdom, 31-42, Woodbridge, Suffolk, UK: Boydell Press

Zorbas, E. (2009). 'What does reconciliation after genocide mean? Public transcripts and hidden transcripts in post-genocide Rwanda' Journal of Genocide Research, 11(1), $127-147$ 
*Ashley DeMartini is a PhD student at McGill University's Department of Integrated Studies in Education. Her current research interests include the representations of difficult histories within educational settings, digital media production, digital literacies, and teacher education.

Ashley DeMartini

3700 McTavish Street

Montreal,

Quebec H3A 1Y2

Ashley.demartini@mail.mcgill.ca 1(514) 6797334 